\title{
FORUM
}

\section{When genetic and phenotypic data do not agree: the conservation implications of ignoring inconvenient taxonomic evidence}

\author{
Nicolas Dussex ${ }^{1,2 *}$, Helen R. Taylor ${ }^{1}$, Martin Irestedt ${ }^{2}$ and Bruce C. Robertson ${ }^{3}$ \\ ${ }^{1}$ Department of Anatomy, University of Otago, PO Box 913, Dunedin 9054, New Zealand \\ ${ }^{2}$ Department of Bioinformatics and Genetics, Swedish Museum of Natural History, Box 50007, Stockholm 10405, Sweden \\ ${ }^{3}$ Department of Zoology, University of Otago, PO Box 56, Dunedin 9054, New Zealand \\ *Author for correspondence (Email: nicolas.dussex@gmail.com)
}

Published online: 7 March 2018

\begin{abstract}
Taxonomy plays a central role in conservation programs of threatened New Zealand taxa. The role of taxonomy is especially relevant for highly vulnerable taxa, where the identification of distinct lineages is essential to define units of conservation and to appropriately allocate conservation resources. Taxonomy traditionally relied on phenotype, but in the past 30 years, the use of genetic data has become prominent in the field. While both phenotypic and genetic approaches to taxonomy have their own merit, they do not always agree. In such cases, favouring one type of data over the other when they are in conflict can have important implications for conservation management. We highlight this issue using several examples from the taxonomy of threatened New Zealand birds. We caution against biases in interpretation of each data type and advocate for a more integrative approach to taxonomy where the limitations of all approaches are carefully considered.
\end{abstract}

Keywords: conservation; genetic; integrative; phenotype; taxonomy

\section{Introduction}

New Zealand's biota is characterised by a high number of endemic taxa, many of which are currently classified as threatened (Duncan \& Blackburn 2004; Robertson et al. 2016). Therefore, it is not surprising that taxonomy plays a major role in the country's conservation programs, in an effort to preserve as many biological entities as possible. Due to its taxonomic uniqueness, documented high extinction rates and vulnerability to introduced predators (Duncan \& Blackburn 2004; Robertson et al. 2016), New Zealand's unique avifauna has been the focus of numerous taxonomic studies. The results of these studies have, in turn, routinely been used to inform conservation programs (e.g. brown kiwi; Baker et al. 1995; Burbidge et al. 2003). Birds' pronounced phenotypic features, including morphology, plumage, behaviour and call variation, have often been used to infer reproductive isolation, making avian taxa a popular focus of speciation and taxonomic studies (e.g. Cracraft 1983). However, the development of phylogenetic approaches to taxonomy has also been an important driver of the delimitation of avian taxa (Cracraft 1983, 1992).

As different types of taxonomic evidence are not always consistent, bird-based studies also provide examples of an overreliance on one particular kind of data (be it morphological, behavioural, or genetic) in taxonomic recommendations. Here, we outline the conservation implications of such taxonomic decisions by discussing several recent avian studies from New Zealand that illustrate this issue. We also reiterate the oft-stated need for an integrative approach, in which multiple lines of evidence are given equal weight (Mayr 1940). Such an 'integrative taxonomy' (Dayrat 2005) is not a new concept, but is particularly important for conservation when phenotypic and genetic data do not coincide geographically. We do not seek to continue the ongoing and complex debate regarding what constitutes a species (Sloan 2013), nor to propose which species concept conservation agencies such as the New Zealand Department of Conservation should use. Rather, we aim to highlight the dangers of relying solely on phenotypic or genetic data to delimit units for conservation. Because the field of taxonomy is complex and in constant evolution, it is crucial that taxonomists and geneticists communicate their recommendations clearly and effectively to non-taxonomists and non-geneticists, and openly acknowledge the limitations of these recommendations.

\section{The importance of taxonomy in conservation}

Recognising units of biodiversity is essential to conserving threatened taxa; naming the taxa that require protection is often the starting point of conservation programs (Mace 2004; Zink 2004). This requirement explains why taxonomy has played a fundamental role in conservation biology in the past few decades (Mace 2004; Bickford et al. 2007).

There are currently around 30 species concepts and definitions (Wheeler \& Meier 2000; Zachos 2016). However, taxonomy has traditionally relied on the biological or morphological species concept, where phenotypic similarities and the ability to interbreed are used to delineate taxonomic units (Cracraft 1983). Over the past 30 years, the development of the phylogenetic species concept, which considers any population that is monophyletic (i.e. that can be traced to a single recent common ancestor) as a species (Cracraft 1983, 1992), has become more prominent as a result of developments in genetic technologies. For instance, the use of genetics for delimitation of taxa has proven extremely valuable for the discovery of cryptic species and lineages (e.g. streak-eared bulbul, Garg et al. 2016) and revising morphology-based 
taxonomy (e.g. modern birds, Jarvis et al. 2014; palaeognaths, Mitchell et al. 2014).

Despite these important contributions, the use of molecular approaches, in particular DNA barcoding, for species identification initially received resistance from the taxonomic community (DeSalle et al. 2005). DNA barcoding was understandably criticised when proposed as a way to replace morphology for classification of taxa (Will \& Rubinoff 2004), in part due to the somewhat forceful, anti-taxonomist stance taken by the original proponents of this approach (Hebert et al. 2003; Hebert \& Barrett 2005). In fact, traditional taxonomic cues are integral to verifying the potential species discovered via DNA barcoding, rendering collaboration between disciplines even more crucial (Taylor \& Harris 2012). Avian taxonomists have increasingly considered various criteria and species concepts when delineating species (Sangster 2014), and we contend that both phenotypic and genetic data are important for taxonomy and should be used together when possible. Combining phenotypic and genetic data is crucial when the principle of reproductive isolation cannot be tested for use in species delineation (which is often the case in endangered and fragmented species). An increasing number of recorded instances of closely related species hybridising and producing fertile (if sometimes less fit) offspring (e.g. black stilt/kāki, Steeves et al. 2010) also implies that decisions based strictly

\section{Phenotype Genotype}

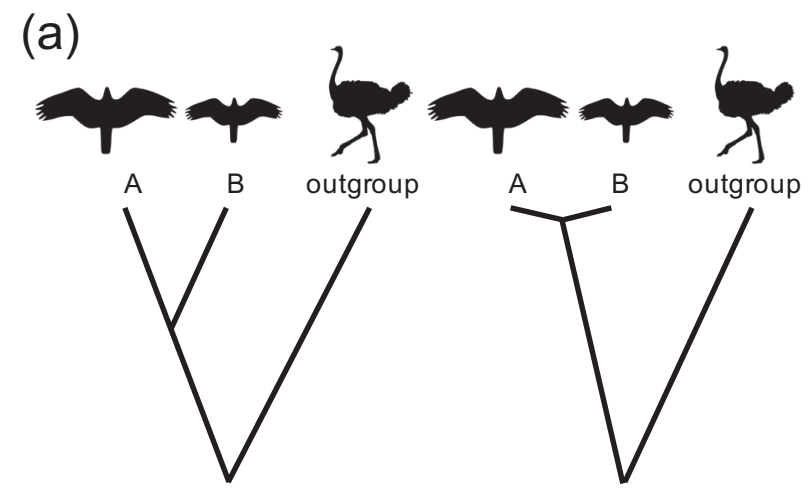

(b)

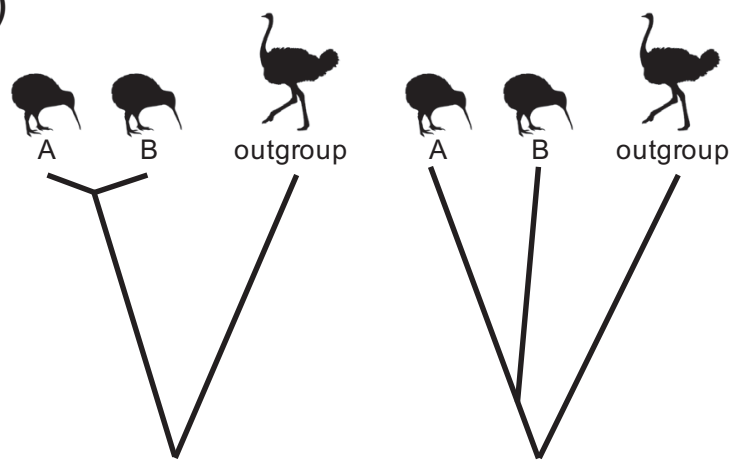

Figure 1. Genotypic and phenotypic data do not always agree. In (a) phenotypic differences between lineages A and B support a designation of two distinct taxa, while the small genetic differentiation supports lineages $\mathrm{A}$ and $\mathrm{B}$ as a single taxon. Conversely, in (b), minimal phenotypic differences support lineages $\mathrm{A}$ and $\mathrm{B}$ as a single taxon, while the large genetic differentiation suggests a degree of reproductive isolation and supports lineages $\mathrm{A}$ and $\mathrm{B}$ as distinct taxa. on the biological species concept could result in phenotypically and genetically distinct taxa not being recognized as full species, and potentially suffering a decreased conservation effort as a result. However, it is possible for phenotype and genetics to tell two different stories regarding species status (Fig. 1). When this happens, it can be challenging for managers to establish the best course of conservation action for the biodiversity in their care.

Making distinctions between various lines of evidence to determine the taxonomic and conservation status of populations is crucial to their effective conservation. For instance, isolated populations of the same species are at risk of inbreeding (Frankham 2005), and mixing them could alleviate these risks (e.g. via genetic rescue; Frankham 2015; Whiteley et al. 2015). Conversely, mixing populations that are actually two genetically distinct species or subspecies may increase the risk of outbreeding depression, breaking up important, locally adapted gene complexes and producing less fit individuals (Edmands 2007; Frankham et al. 2011). While we do not advocate for genetic rescue as a panacea for all conservation programs, we believe that it is crucial to have an informed discussion on the risks and benefits of this approach and on how taxa and units of conservations are delimited. An informed decision is only possible when multiple lines of evidence, including both genetics and phenotype, are carefully considered.

As delineating taxa can be complex, Moritz (1999) proposed focusing on maintaining and restoring evolutionary processes (e.g. adaptation to changing selective pressures) using molecular tools rather than phenotypes, an approach that does not require changes in taxonomy (Moritz 1994a, b). He defined evolutionarily significant units (ESUs) representing historically isolated and independently evolving sets of populations, and management units (MUs) representing demographically independent populations. However, most conservation management plans still rely on formal species and sub-species designations, and defining units for conservation remains problematic when geographical variation in phenotype and molecular data do not coincide (Avise \& Ball 1990; O’Brien \& Mayr 1991; Moritz 1999).

\section{Causes of conflict between molecular and phenotypic data}

Molecular and phenotypic data may not fully coincide for a number of reasons. For example, phenotypic variation along a geographical cline may be used to support the division of a species into several subspecies. However, if genetic data suggest extensive gene flow along the cline, then the phenotypic variation could be an example of Bergmann's rule. In such cases, individuals within a species vary phenotypically along a geographical cline due to gradual changes in the environment along that cline. The phenotypic variation is maintained by either evolutionary adaptation or phenotypic plasticity (Bergmann 1847; Salewski \& Watt 2016). When Bergmann's rule is in effect, it is dubious to designate populations of a species in different locations along the cline as distinct subspecies (e.g. barn owl, Antoniazza et al. 2010; house sparrow, Brommer et al. 2014; kākā, Dussex et al. 2015).

Other examples of phenotypic plasticity such as epigenetic effects (changes in expression of DNA but not in the actual DNA sequence) can also explain phenotypic variation in the absence of genetic differentiation, such as that associated with 
growth and development (Sanchez \& Schoch 2013; Tobi et al. 2014; Triantaphyllopoulos et al. 2016). Finally, an increasing number of genome-wide studies suggest that slight changes to small portions of a species' genome can alter the phenotype of key adaptive traits, such as plumage coloration (e.g. carrion and hooded crows, Poelstra et al. 2014; golden-winged/bluewinged warbler complex, Toews et al. 2016) or beak shape (Darwin's finches, Chaves et al. 2016) in birds. Similarly, adaptation to high altitude (Yi et al.2010) or skin pigmentation (Wilde et al. 2014) in humans is underpinned by just a few genomic regions. One of the most compelling examples of small genomic differences underpinning large phenotypic polymorphism within a species is that seen in dogs (Canis lupus familiaris), with a maximum of three loci explaining the majority of phenotypic variation among 80 dog breeds, all of which look very different morphologically, but none of which are reproductively isolated from one another (Boyko et al. 2010). These examples suggest that phenotype alone is not always sufficient or appropriate for delineating taxa, and can often be misleading. The limitation of relying solely on phenotype does not mean that phenotypically-distinct units do not deserve particular attention and sometimes afforded conservation status (e.g. kākā, Dussex et al. 2015), but that considering all the evidence (both phenotypic and genetic) where possible, is key to effective species management.

\section{Examples of conflict between molecular and phenotypic data in New Zealand birds}

Despite various efforts to develop an 'integrative taxonomy' and successful examples of this approach (e.g. Baker et al. 2003), molecular or phenotypic data are often still favoured over each other. Some recent studies relevant to the conservation of New Zealand avian species provide excellent examples of this point.

For instance, the New Zealand falcon/kārearea (Falco novaeseelandiae) has previously been described as comprising three morphologically and ecologically distinct races or forms: the bush falcon, found in the North Island and in the northwest of the South Island; the southern falcon, found in coastal Fiordland; and the eastern falcon from most of the rest of the South Island (Fox 1977, 1988; Robertson et al. 2016). Fox (1977) initially proposed to erect these three forms to sub-species. In contrast, a recent study argues for the recognition of two subspecies (Trewick \& Olley 2016) based almost entirely on distinct wing size clusters observed between New Zealand falcon in the North and South Islands, suggesting that Cook Strait is a dispersal barrier between the two groups. However, the range-wide genetic panmixia (i.e. unhindered gene flow and random mating) reported in the same study supports a complete absence of population substructure. Ignoring this finding, the authors invoke adaptive change along a 'stepped environmental cline' to support the designation of a North Island (F. n. ferox) and a South Island (F. n. novaeseelandiae) subspecies (Trewick \& Olley 2016). This preference for a phenotype-based taxonomy is at odds with other avian studies based on variable phenotype and/or genetic data in New Zealand (e.g. Dussex et al. 2015) and elsewhere (Antoniazza et al. 2010) that do not suggest official designation of subspecies. Unfortunately, the sampling regime employed in this new study makes it impossible for the authors to test Fox's (1977) original hypothesis of three morphologies. Surprisingly, Trewick and Olley (2016) do mention a study on guppies (Fitzpatrick etal. 2015) supporting the maintenance of divergent phenotypes via local adaptation despite gene flow, further supporting our argument that phenotypic differentiation can happen without leading to incipient speciation.

Genetic data are not immune to being over-interpreted for taxonomy and even studies that are heavily caveated by their authors can be misused for conservation. For example, kiwi (Apteryx spp.) are a compelling example of the implications of discovering several distinct genetic lineages among morphologically cryptic forms (Baker et al. 1995; Burbidge et al. 2003; Shepherd \& Lambert 2008; Weir et al. 2016). A recent study using a large number (6332) of single nucleotide polymorphism (SNP) markers identified 11 extant genetic lineages, which the authors suggest were created by natural (i.e. non-human-driven) processes (Weir et al. 2016). This conclusion is based on three sound lines of evidence: (1) the timing of lineage diversification coinciding with glaciations of the Plesitocene; (2) the range and location of Holocene fossils demonstrating allopatry after glaciations; and (3) signatures of population declines resulting from isolation in refugia during the last glacial cycle. Despite the robustness of these results and because of the recent divergence of these lineages, the authors are cautious not to position these lineages as separate species or subspecies and even raise the possibility of hybridisation among lineages within the same species. In fact, hybridisation has recently been demonstrated between little spotted kiwi and rowi (K. Ramstad, unpubl. data), which are separated by at least 3.85 my of evolution (Weir et al. 2016). Importantly, the authors heavily caveat their findings with a need to investigate phenotypic differences (i.e. vocalisation and olfaction) associated with territoriality and mate recognition that may lead to reproductive isolation (in which case the delineation of subspecies might be warranted). We agree with these considerations and further argue that estimating the proportion of this differentiation accounted for by neutral and selectively adaptive (e.g. locally adapted) genomic regions is crucial in order to assess the need to manage these lineages independently.

In spite of Weir et al.'s (2016) responsible and conservative approach, this paper's findings are already being misinterpreted by conservation managers. We have heard three different practitioners from the New Zealand Department of Conservation describe the three identified lineages within the recognised tokoeka kiwi species as separate species and subspecies based on Weir et al.'s (2016) paper (H. Taylor pers. obs.). This could be a result of some of the language used by Weir et al. (2016). For instance, the authors consider the possibility that these 11 taxa represent a case of 'incipient speciation (i.e. subspecies) that, if given enough time, may evolve into full species' (Weir et al. 2016). While this statement is plausible in terms of evolutionary theory (i.e. allopatric speciation), it seems to have left the door open for misinterpratetion, especially where there is a lack of awareness of the nature (i.e. selectively neutral or adaptive) of this pattern. While the distinction between incipient and full species may be considered by geneticists as a mere semantic issue, we fear that this wording may reinforce the concept of species as fixed entities in spite of the growing evidence for species hybridisation being a common phenomemon (Arnold 2015; Ottenburghs et al.2015; vonHoldt et al.2017), including in kiwi (K. Ramstad, unpubl. data). One important consequence of this misunderstanding may be a diversion of limited conservation resources from other endangered species to such presumed 'distinct lineages'. This diversion is worrying for conservation of New Zealand taxa as a whole and illustrates how careful researchers working on taxonomic delineation need to be when 
communicating their findings to practitioners.

Even extinct taxa are not immune from conflicts between phenotypic and genetic taxonomic evidence. Recently, it was suggested that New Zealand once had its own giant swan, Cygnus sumnerensis, a distinct species from the Australasian black swan seen in New Zealand today (C. atratus) (Rawlence et al. 2017). The same study also argues that the giant swan found in New Zealand was a distinct sub-species from that found on the Chatham Islands (C. s. chathamicus). While this study clearly adopts an integrative approach to taxonomy by using both morphological and genetic evidence, the conclusion to delineate species mainly hinges on morphological data. Although the authors admit in their supplementary information that 'species delimitation based on single-marker gene trees should be treated with caution', they proceed to declare a new species of swan based on $1.4 \%$ divergence (i.e. five step-wise differences) between mitochondrial haplotypes, and a New Zealand and Chatham Island sub-species division on $0.3 \%$ divergence (i.e. a single step-wise difference). This information is presented in tandem with more convincing morphological data, suggesting that the New Zealand form of the swan was typical of island avifauna (Grant 1965) with larger body size, elongated limbs, and shortened wings. This example not only demonstrates a preference for one type of data when it tells a more exciting story, but also supports the need to assess both neutral and selective genetic diversity when delineating taxa.

In contrast, studies of New Zealand's blue duck/whio (Hymenolaimus malacorhynchos) are much more cautious when interpreting genetic data. There is $1.9 \%$ divergence (i.e. 17 step-wise differences) between mitochondrial DNA haplotypes in North Island and South Island populations of this species (Grosser et al. 2017). Also, nuclear data for blue duck/ whio suggest a distinct North Island and South Island genetic cluster. In spite of these genetic differences and in the face of limited morphological data (Robertson et al. 2007), researchers have taken a conservative approach, pointing out that gaps in sampling mean they cannot rule out a genetic cline rather that two discrete subspecies. They advocate for additional secure conservation sites based on genetic distinctiveness, but at no point suggest these are two different subspecies (Grosser et al. 2017).

At an even finer geographical scale, there is 3.7\% divergence between mitochondrial haplotypes in rock wren (Xenicus gilviventris) in populations from the north and south of New Zealand's South Island (Weston \& Robertson 2015). This split is supported by nuclear genetic data, but researchers are again cautious, suggesting these might be separate evolutionarily significant units, but never using the term sub-species and advising more data are required (Weston \& Robertson 2015). The taxonomy of extinct lineages is arguably less important for current conservation management, but illustrates the point that there is no standardised approach to species delineation with genetic data. It is important to consider why two suggested species/subspecies might show relatively low genetic divergence in tandem with phenotypic differences, especially if only one or a few markers are available.

\section{Integrative taxonomy}

While taxonomy should strive to provide clear answers when delimiting taxa, it is not an exact science in which species represent pure and fixed entities (Mace 2004). Rather, species names should be considered as hypotheses (Hey et al. 2003;
Mace 2004) about which predictions are made (Valdecasas et al. 2008). In fact, this difficulty in delineating species has contributed to a certain level of anarchy in the discipline (Garnett \& Christidis 2017), because species tend to be delimited arbitrarily according to one of at least 30 definitions of species (Zachos 2016). Consequently, this lack of clarity can hamper conservation efforts because the concept of species as fixed entities is often at the core of conservation programs (Garnett \& Christidis 2017). Moreover, the finding that hybridisation between species/subspecies is a more common phenomemon than previously thought (Arnold 2015; vonHoldt et al. 2017) and the lack of protection status of these hybrids in most conservation legislation(e.g. US Endangered Species Act; Haig \& Allendorf 2006) further complicates the determination of the taxonomic and conservation status of wild populations.

The most theoretically sound way to delimit new taxa is an 'integrative taxonomy', where multiple perspectives (e.g. phylogeography, comparative morphology, population genetics, ecology, development, behaviour, etc.) are considered (De Queiroz 2007; Pante et al. 2015). Combining these various approaches will in turn bridge the divide between molecular-based and phenotype-based taxonomy (Dayrat 2005; Padial et al. 2010; Riedel et al. 2013). A good example of the application of this approach is the recent reclassification of the wide-ranging Indo-Pacific red-bellied pitta (Erythropitta erythrogaster) (Irestedt et al. 2013). Using a combination of genetics, morphometrics, plumage differences and song variation, researchers proposed that this single 'polytypic' (i.e. with several variant forms) species is actually 17 species. Importantly, even with all the different types of evidence supporting their hypothesis, the authors of this study remain cautious, stating that reproductive isolation is speculative, and implying that even more data are required to fully understand this species complex. The authors also add that molecular species delimitation methods may provide a starting point for integrative taxonomic studies, but reiterate that genetics alone may be insufficient to accurately identify all species. This clear emphasis on integration of many different kinds of data is a helpful template for other studies. The same reasoning and caution should be applied to species management; all available evidence should be considered when developing conservation guidelines rather than whatever data conveniently fits the current management practices.

\section{Conclusion}

Taxonomy is unquestionably an important tool for conservation practitioners and is often at the core of management plans (Mace 2004). However, caution is required as species names may often be considered as strong evidence that taxa are pure units and new classifications may often not be questioned, especially if they are in line with current management plans. Conservation decisions should not blindly follow taxonomic recommendations as the main task for taxonomists is not to conserve biodiversity per se but to categorise it. Moreover, we wonder about the impact of such a revised classification on management decisions. For instance, if a species is more finely split than another, more money may be invested in the conservation of the former than the latter (Garnett \& Christidis 2017). This may thus divert resources from an endangered species to presumed 'distinct lineages' within what is, overall, a less endangered species.

We are also concerned that, often, important taxonomic 
changes that may have great impact on conservation decisions are proposed based on only one type of evidence, even when another type of evidence contradicts it (e.g. New Zealand falcon, Trewick \& Olley 2016). Therefore, it is crucial to consider how strong the evidence is for a particular taxonomic hypothesis (i.e. assess whether several lines of evidence in conflict or consistent) as taxonomic recommendations may arbitrarily favour one line of evidence (morphological, behavioral or molecular) over others. While the scientific community is responsible for caveating their findings to avoid undesirable outcomes for conservation programs, conservation practitioners should also consider taxonomy with some caution and instead reflect on how their management strategy will impact the maintenance of species, populations and biodiversity as a whole.

Favouring phenotypic differences over molecular data may lead to reduced credibility of genetics as a sound conservation tool as a whole (Allendorf et al. 2010; Frankham 2010). Genetics is still not well-integrated in conservation practice globally (Cook \& Sgrò 2016; Pierson et al. 2016). The increasing use of genomics (whereby data are gathered from across the entire genome rather than just very small sections of it) has the potential to widen this research implementation gap (Shafer et al.2015). Genetics as a management tool is generally positively perceived by conservation practitioners in New Zealand (Taylor et al. 2017). However, because many researchers still rely on single-gene data, owing to the prohibitive cost of whole-genome sequencing in New Zealand, great caution should be exercised when interpreting genetic data to avoid an ambivalence towards genetic tools for conservation. Moreover, researchers casting aside technically sound molecular data during taxonomic investigations (e.g. Trewick \& Olley 2016) could further contribute to this ambivalence. While we acknowledge the challenges in obtaining both molecular and phenotypic data, we recommend that, in order to avoid this ambivalence towards genetics and to avoid erroneous species classifications in general, equal weight should be given to all lines of taxonomic evidence.

We acknowledge that when phenotypic and genetic data are both available, but do not agree, drawing conclusions can be challenging. In such cases, it is crucial for researchers to advise caution, and caveat their findings to ensure their data are not unintentionally misinterpreted by conservation practitioners. Divergence between phenotypic and genetic data is intriguing and should lead to further investigation rather than firm recommendations. Strongly advocating for the pattern supported by one kind of data or the other could lead to improper conservation management decisions, potentially harming the survival probabilities of threatened taxa. Our opinions and assertions expressed in this piece are by no means novel. However, the publication of at least three papers in the past year that exemplify the issues inherent in ignoring inconvenient lines of evidence for species classification, illustrates that the message of integrative taxonomy bears repeating.

\section{References}

Allendorf FW, Hohenlohe PA, Luikart G 2010. Genomics and the future of conservation genetics. Nature reviews. Genetics 11: 697-709.

Antoniazza S, Burri R, Fumagalli L, Goudet J, Roulin A 2010. Local adaptation maintains clinal variation in melaninbased coloration of European barn owls (Tyto alba). Evolution 64: 1944-1954.
Arnold ML 2015. Dvergence with genetic exchange. Oxford University Press. 272 p.

Avise JC, Ball RM 1990. Principles of genealogical concordance in species concepts and biological taxonomy. Oxford Surveys in Evolutionary Biology 7: 45-67.

Baker AJ, Daugherty CH, Colbourne R, McLennan JL 1995. Flightless brown kiwis of New Zealand possess extremely subdivided population structure and cryptic species like small mammals. Proceedings of the National Academy of Sciences of the United States of America 92: 8254-8258.

Baker AM, Bartlett C, Bunn SE, Goudkamp K, Sheldon F, Hughes JM 2003. Cryptic species and morphological plasticity in long-lived bivalves (Unionoida: Hyriidae) from inland Australia. Molecular Ecology 12:2707-2717.

Bergmann C 1847. Über Die Verhaltnisse Der Warmeokonomie Der Thiere Zu Ihrer Grosse. Götting. Stud. 1: 595-708.

Bickford D, Lohman DJ, Sodhi NS, Ng PKL, Meier R, Winker K, Ingram KK, Das I 2007. Cryptic species as a window on diversity and conservation. Trends in Ecology and Evolution 22: 148-155.

Boyko AR, Quignon P, Li L, Schoenebeck JJ, Degenhardt JD, Lohmueller KE, Zhao K, Brisbin A, Parker HG, VonHoldt BM, Cargill M, Auton A, Reynolds A, Elkahloun AG, Castelhano M, Mosher DS, Sutter NB, Johnson GS, Novembre J, Hubisz MJ, SiepelA, Wayne RK, Bustamante CD, Ostrander E 2010. A simple genetic architecture underlies morphological variation in dogs. PLoS Biology 8: 49-50.

Brommer JE, Hanski IK, Kekkonen J, Väisänen RA 2014. Size differentiation in Finnish house sparrows follows Bergmann's rule with evidence of local adaptation. Journal of Evolutionary Biology 27: 737-747.

Burbidge ML, Colbourne RM, Robertson HA, Baker AJ 2003. Molecular and other biological evidence supports the recognition of at least three species of brown kiwi. Conservation Genetics 4: 167-177.

Chaves JA, Cooper EA, Hendry AP, Podos J, De León LF, Raeymaekers JAM, MacMillan WO, Uy JAC 2016. Genomic variation at the tips of the adaptive radiation of Darwin's finches. Molecular Ecology 25: 5282-5295.

Cook CN, Sgrò CM 2016. Aligning science and policy to achieve evolutionarily enlightened conservation management. Conservation Biology 31: 501-512.

Cracraft J 1983. Species concepts and speciation analysis. In: Johnston RF ed. Current ornithology. Volume 1. Boston, MA, Springer. Pp. 159-187.

Cracraft J 1992. The species of the birds-of-paradise (Paradiseidae): applying the phylogenetic species concept to a complex pattern of diversification. Cladistics 8: 1-43.

Dayrat B 2005. Towards integrative taxonomy. Biological Journal of the Linnean Society 85: 407-415.

De Queiroz K 2007. Species concepts and species delimitation. Systematic Botany 56: 879-886.

DeSalle R, Egan MG, Siddall M 2005. The unholy trinity: taxonomy, species delimitation and DNA barcoding. Philosophical transactions of the Royal Society of London. Series B, Biological Sciences 360: 1905-1916.

Duncan RP, Blackburn TM 2004. Extinction and endemism in the New Zealand avifauna. Global Ecology and Biogeography 13: 509-517.

Dussex N, Sainsbury J, Moorhouse R, Jamieson IG, Robertson BC 2015. Evidence for Bergmann's rule and not allopatric subspeciation in the threatened kaka (Nestor meridionalis). Journal of Heredity 106: 1-13. 
Edmands S 2007. Between a rock and a hard place: evaluating the relative risks of inbreeding and outbreeding for conservation and management. Molecular Ecology 16: 463-475.

Fitzpatrick SW, Gerberich JC, Kronenberger JA, Angeloni LM, Funk WC 2015. Locally adapted traits maintained in the face of high gene flow. Ecology Letters 18: 37-47.

Fox N 1977. The biology of the New Zealand falcon (Falco navaeseelandiae Gmelin 1788). Unpublished $\mathrm{PhD}$ thesis, University of Canterbury, New Zealand. $474 \mathrm{p}$.

Fox N 1988. A taxonomic redescription of the New Zealand Falcon, Falco novaeseelandiae Gmelin, 1788. Notornis 35: 270-272.

Frankham R 2005. Genetics and extinction. Biological Conservation 126: 131-140.

Frankham R 2010. Where are we in conservation genetics and where do we need to go? Conservation Genetics 11: 661-663.

Frankham R 2015. Genetic rescue of small inbred populations: meta-analysis reveals large and consistent benefits of gene flow. Molecular Ecology 24: 2610-2618.

Frankham R, Ballou JD, Eldridge MDB, Lacy RC, Ralls K, Dudash MR, Fenster CB 2011. Predicting the probability of outbreeding depression. Conservation Biology: the Journal of the Society for Conservation Biology 25: 465-475.

Garg KM, Tizard R, Ng NSR, Cros E, Dejtaradol A, Chattopadhyay B, Pwint N, Päckert M, Rheindt FE 2016. Genome-wide data help identify an avian species-level lineage that is morphologically and vocally cryptic. Molecular Phylogenetics and Evolution 102: 97-103.

Garnett ST, Christidis L 2017. Taxonomy anarchy hampers conservation. Nature 546: 25-27.

Grant PR 1965. The adaptive significance of some size trends in island birds. Evolution 19: 355-367.

Grosser S, Abdelkrim J, Wing J, Robertson BC, Gemmell NJ 2017. Strong isolation by distance argues for separate population management of endangered blue duck (Hymenolaimus malacorhynchos). Conservation Genetics 18: 327-341.

Haig SM, Allendorf FW 2006. Hybrids and policy. In: Scott JM, Goble DD, Davis F eds. The Endangered Species Act at thirty, Volume 2: conserving biodiversity in humandominated landscapes. Chicago, Island Press. Pp. 150-163.

Hebert PDN, Barrett RDH 2005. Reply to the comment by L. Prendini on "Identifying spiders through DNA barcodes." Canadian Journal of Zoology 83: 505-506.

Hebert PDN, Cywinska A, Ball SL, deWaard JR 2003. Biological identifications through DNA barcodes. Proceedings of the Royal Society B: Biological Sciences 270: 313-321.

Hey J, Waples RS, Arnold ML, Butlin RK, Harrison RG 2003. Understanding and confronting species uncertainty in biology and conservation. Trends in Ecology and Evolution 18: 597-603.

Irestedt M, Fabre P-H, Batalha-Filho H, Jønsson KA, Roselaar CS, Sangster G, Ericson PGP 2013. The spatio-temporal colonization and diversification across the Indo-Pacific by a "great speciator" (Aves, Erythropitta erythrogaster). Proceedings of the Royal Society B: Biological Sciences 280: 20130309.

Jarvis ED, Mirarab S, Aberer AJ, Li B, Houde P, Li C, Ho SYW, Faircloth BC, Nabholz B, Howard JT, Suh A, Weber CC, da Fonseca RR, Li J, Zhang F, Li H, Zhou L, Narula N, Liu L, Ganapathy G, Boussau B, Bayzid MS, Zavidovych
V, Subramanian S, Gabaldón T, Capella-Gutiérrez S, Huerta-Cepas J, Rekepalli B, Munch K, Schierup M 2014. Whole-genome analyses resolve early branches in the tree of life of modern birds. Science 346: 1126-1138.

Mace GM 2004. The role of taxonomy in species conservation. Philosophical transactions of the Royal Society of London. Series B, Biological Sciences 359: 711-719.

Mayr E 1940. Speciation phenomena in birds. The American Naturalist 74: 249-278.

Mitchell KJ, Llamas B, Soubrier J, Rawlence NJ, Worthy TH, Wood J, Lee MSY, Cooper A 2014. Ancient DNA reveals elephant birds and kiwi are sister taxa and clarifies ratite bird evolution. Science 344: 898-900.

Moritz C 1994a. Defining "Evolutionarily Significant Units". Trends in Ecology and Evolution 9: 373-375.

Moritz C 1994b. Applications of mitochondrial DNA analysis in conservation: a critical review. Molecular Ecology 3: 401-411.

MoritzC 1999. Conservation units and translocations: stategies for conserving evolutionary processes. Hereditas 130: 217-228.

O’Brien SJ, Mayr E 1991. Bureaucratic mischief: recognizing endangered species and subspecies. Science 251: 1187-1188.

Ottenburghs J, Ydenberg RC, Van Hooft P, Van Wieren SE, Prins HHT 2015. The avian hybrids project: gathering the scientific literature on avian hybridization. Ibis 157 : 892-894.

Padial JM, Miralles A, De la Riva I, Vences M 2010. The integrative future of taxonomy. Frontiers in zoology 7: 16.

Pante E, Schoelinck C, Puillandre N 2015. From integrative taxonomy to species description: one step beyond. Systematic Biology 64: 152-160.

Pierson JC, Coates DJ, Oostermeijer JGB, Beissinger SR, Bragg JG, Sunnucks P, Schumaker NH, Young AG 2016. Genetic factors in threatened species recovery plans on three continents. Frontiers in Ecology and the Environment 14: 433-440.

Poelstra JW, Vijay N, Bossu CM, Lantz H, Ryll B, Müller I, Baglione V, Unneberg P, Wikelski M, Grabherr MG, Wolf JBW 2014. The genomic landscape underlying phenotypic integrity in the face of gene flow in crows. Science 344: 1410-1414.

Rawlence NJ, Kardamaki A, Easton LJ, Tennyson AJD, Scofield RP, Waters JM 2017. Ancient DNA and morphometric analysis reveal extinction and replacement of New Zealand's unique black swans. Proceedings of the Royal Society B: Biological Sciences 284: 20170876.

Riedel A, Sagata K, Suhardjono YR, Tänzler R, Balke M 2013. Integrative taxonomy on the fast track - towards more sustainability in biodiversity research. Frontiers in zoology 10: 15.

Robertson BC, Steeves TE, McBride KP,Goldstien SJ, Williams M, Gemmell NJ 2007. Phylogeography of the New Zealand blue duck (Hymenolaimus malacorhynchos): implications for translocation and species recovery. Conservation Genetics 8: 1431-1440.

Robertson HA, Baird K, Dowding JE, Elliott GP, Hitchmough RA, Miskelly CM, McArthurN, O’Donnell CFJ, SagarPM, Scofield RP, Taylor GA2016. Conservation status of New Zealand birds, 2016. New Zealand Threat Classification Series 19. Wellington, Department of Conservation. $26 \mathrm{p}$.

Salewski V, Watt C 2016. Bergmann's rule: a biophysiological rule examined in birds. Oikos126: 161-172. 
Sanchez S, Schoch RR 2013. Bone histology reveals a high environmental and metabolic plasticity as a successful evolutionary strategy in a long-lived homeostatic Triassic Temnospondyl. Evolutionary Biology 40: 627-647.

Sangster G 2014. The application of species criteria in avian taxonomy and its implications for the debate over species concepts. Biological Reviews 89: 199-214.

Shafer ABA, Wolf JBW, Alves PC, Bergström L, Bruford MW, Brännström I, Colling G, Dalén L, De Meester L, Ekblom R, Fawcett KD, Fior S, Hajibabaei M, Hill JA, HoezelAR, Höglund J, Jensen EL, Krause J, Kristensen TN, Krützen M, McKay JK, Norman AJ, Ogden R, Österling EM, Ouborg NJ, Piccolo J, Popović D, Primmer CR, Reed FA, Roumet M, Salmona J, Schenekar T, Schwartz MK, Segelbacher G, Senn H, Thaulow J, Valtonen M, Veale A, Vergeer P, Vijay N, Vilà C, Weissensteiner M, Wennerström L, Wheat CW, Zieliński P 2015. Genomics and the challenging translation into conservation practice. Trends in Ecology \& Evolution 30: 78-87.

Shepherd LD, Lambert DM 2008. Ancient DNA and conservation: lessons from the endangered kiwi of New Zealand. Molecular Ecology 17: 2174-2184.

Sloan PR 2013. The species problem and history. Studies in History and Philosophy of Biological and Biomedical Sciences 2: 237-241.

Steeves TE, Maloney RF, Hale ML, Tylianakis JM, Gemmell NJ 2010. Genetic analyses reveal hybridization but no hybrid swarm in one of the world's rarest birds. Molecular Ecology 19: 5090-5100.

Taylor HR, Harris WE 2012. An emergent science on the brink of irrelevance: a review of the past 8 years of DNA barcoding. Molecular Ecology Resources 12: 377-388.

Taylor HR, Dussex N, van Heezik Y 2017. Bridging the conservation genetics gap by identifying barriers to implementation for conservation practitioners. Global Ecology and Conservation 10: 231-242.

Tobi EW, Goeman JJ, Monajemi R, Gu H, Putter H, Zhang Y, Slieker RC, Stok AP, Thijssen PE, Müller F, Van Zwet EW, Bock C, Meissner A, Lumey LH, Slagboom PE, Heijmans BT 2014. DNA methylation signatures link prenatal famine exposure to growth and metabolism. Nature Communications 5: 1-13.

Toews DPL, Taylor SA, Vallender R, BrelsfordA, ButcherBG, Messer PW, Lovette IJ 2016. Plumage genes and little else distinguish the genomes of hybridizing warblers. Current Biology 26: 2313-2318.

Trewick SA, Olley L 2016. Spatial size dimorphism in New Zealand's last endemic raptor, the kārearea Falco novaeseelandiae, coincides with a narrow sea strait. Ibis 158: 747-761.

Editorial board member: Jamie Wood

Received 7 September 2017; accepted 6 December 2017
Triantaphyllopoulos KA, Ikonomopoulos I, Bannister AJ 2016. Epigenetics and inheritance of phenotype variation in livestock. Epigenetics \& Chromatin 9: 31.

Valdecasas AG, Williams D, Wheeler QD 2008. "Integrative taxonomy" then and now: a response to Dayrat (2005). Biological Journal of the Linnean Society 93: 211-216.

vonHoldt BM, Brzeski KE, Wilcove DS, Rutledge L 2017. Redefining the role of admixture and genomics in species conservation. Conservation Letters. DOI: 10.1111/ conl.12371.

Weir JT, Haddrath O, Robertson HA, Colbourne RM, Baker AJ 2016. Explosive ice age diversification of kiwi. Proceedings of the National Academy of Sciences of the United States of America 113: 5580-5587.

Weston KA, Robertson BC 2015. Population structure within an alpine archipelago: strong signature of past climate change in the New Zealand rock wren (Xenicus gilviventris). Molecular Ecology 24: 4778-4794.

Wheeler QD, Meier R 2000. Species concepts and phylogenetic theory: a debate. New York, Columbia University Press. $229 \mathrm{p}$.

Whiteley AR, Fitzpatrick SW, Funk WC, Tallmon DA 2015. Genetic rescue to the rescue. Trends in Ecology and Evolution 30: 42-49.

Wilde S, Timpson A, Kirsanow K, Kaiser E, Kayser M, Unterländer M, Hollfelder N, Potekhina ID, Schier W, Thomas MG, Burger J 2014. Direct evidence for positive selection of skin, hair, and eye pigmentation in Europeans during the last 5,000 y. Proceedings of the National Academy of Sciences of the United States of America 111: 4832-4837.

Will KW, Rubinoff D 2004. Myth of the molecule: DNA barcodes for species cannot replace morphology for identification and classification. Cladistics 20: 47-55.

Yi X, Liang Y, Huerta-Sanchez E, Jin X, Cuo ZX, Pool JE, Xu $X$, Jiang H, Vinckenbosch N, Korneliussen, T S, Zheng H, Liu T, He W, Li K, Luo R, Nie X, Wu H, Zhao M, Cao H, Zou J, Shan Y, Li S, Yang Q, Asan, Ni P, Tian G, Xu J, Liu X, Jiang T, Wu R, Zhou G, Tang M, Qin J, Wang T, Feng S, Li G, Huasang Luosang J, Wang W, Chen F, Wang Y, Zheng X, Li Z, Bianba Z, Yang G, Wang X, Tang S, Gao G, Chen Y, Luo Z, Gusang L, Cao Z, Zhang Q, Ouyang W, Ren X, Liang H, Zheng H, Huang Y, Li J, Bolund L, Kristiansen K, Li Y, Zhang Y, Zhang X, Li R, Li S, Yang H, Nielsen R, Wang J 2010. Sequencing of 50 human exomes reveals adaptation to high altitude. Science 329: 75-78.

Zachos FE 2016. Species concepts in biology. Springer. 220 p.

Zink RM 2004. The role of subspecies in obscuring avian biological diversity and misleading conservation policy. Proceedings of the Royal Society B: Biological Sciences 271: 561-564. 